\title{
A potential biomarker for colorectal cancer: long non-coding RNA RP1-13P20.6
}

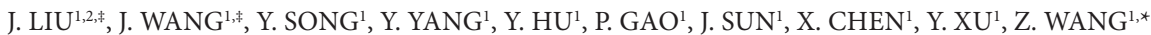

${ }^{1}$ Department of Surgical Oncology and General Surgery, First Hospital of China Medical University, 155 North Nanjing Street, Heping District, Shenyang, 110001, China; ${ }^{2}$ Department of Gastroenterology Surgery, the Second Hospital of Jilin University, 218 Ziqiang street, Changchun, 130021, China

${ }^{*}$ Correspondence: josieon826@sina.cn

${ }^{*}$ Contributed equally to this work.

\section{Received April 21, 2016 / Accepted July 18, 2016}

\begin{abstract}
Long non-coding RNAs (lncRNAs) occupy the majority of the human genome. Their dysregulation is usually related with the procession of diseases, including tumors. Abnormally expressed lncRNAs have been found in colorectal cancer (CRC), but are not fully understood. In the current study, we determined the expression level of a novel lncRNA-RP1-13P20.6 in 99 pairs of CRC tissues compared to their matched normal adjacent tissues, using real time polymerase chain reaction. We further assessed the correlation between their expression levels and their clinicopathological parameters, and determined the potential of RP1-13P20.6 as a biomarker for CRC. The expression of lncRNA-RP1-13P20.6 in CRC tissues and cell lines decreased significantly with an area under the curve (AUC) of $0.755(\mathrm{p}<0.001)$. However, there was no significant difference between the expression levels of lncRNA-RP1-13P20.6 and the clinicopathological characteristics. The abnormal expression level and AUC values suggest that lncRNA-RP1-13P20.6 is a potential biomarker for CRC.
\end{abstract}

Key words: long non-coding RNA, colorectal cancer, RP1-13P20.6, biomarker

Colorectal cancer (CRC) is the third most common cancer, causing cancer-related deaths worldwide [1]. CRC has the fifth highest incidence and presents the fifth leading cause of cancer death in China [2]. In contrast to the increasing incidence, the mortality rate of $\mathrm{CRC}$ has been decreasing due to population-based CRC screening and improved treatments in many countries. However, screening is only performed in a few cities of China because of the large population and inadequate resources [3]. Furthermore, the CRC patients have usually reached a late stage of cancer when they are diagnosed, which lowers the quality of life. Detection at an early time is significantly beneficial to patients suffering from CRC. Therefore, exploring the initial and developmental mechanisms of CRC, and identifying novel molecular markers are critical.

Non-coding RNAs (ncRNAs), comprise up to $75 \%$ of the entire genome in humans, which are disable to code proteins and usually perform as significant regulatory roles in multiple biological processes [4]. Long non-coding RNAs (lncRNAs), which are defined as being longer than 200 nucleotides, represent the most prevalent class in ncRNAs [5]. LncRNAs are poorly conserved compared to the small ncRNAs, and they regulate the targeted genes at the level of chromatin modi- fication, transcription and post-transcriptional processing [6-7]. Recent years, the aberrant expressions of lncRNAs have been reported in multiple cancers, such as in breast cancer, hepatocellular carcinoma, gastric cancer, and glioma [8-11]. H19, GAS5, and CRNDE are typical cancer-related lncRNAs, and the dysregulation of these lncRNAs is usually associated with progression, invasion, and metastasis in cancers [12-14]. LncRNAs function depending on their locations in cancer cells. They are located mainly the in nucleus [15], while a subset of lncRNAs in the cytoplasm participate in the process of tumor growth by regulating the location of proteins, the translation of mRNAs, and the stability of mRNAs [16-17]. By interacting with mRNAs, microRNAs and proteins, lncRNAs participate in diverse biological processes [18-19]. However, the exact mechanisms of lncRNAs acting on the targeted genes are not fully understood.

RP1-13P20.6, one of the lncRNAs, is located on the reversed strand in 1q21 region with a length of $1997 \mathrm{nts}$ according to the UCSC Genome Bioinformatics (http://genome. ucsc.edu/index.html). Previous researches have revealed that a cluster of genes in this region including S100 calcium binding protein A (S100A) family and small proline-rich pro- 
teins (SPRRs) family play important roles in the genesis and progress in colorectal cancer.[20-21] However, there isn't any evidence whether the lncRNA- RP1-13P20.6 in this famous region relates to the colorectal cancer. This current study investigated the relative expression of the novel lncRNA RP113P20.6 in cancerous tissues and the relationship between the expression level and the clinicopathological characteristics of in CRC patients.

\section{Patients and methods}

Patients and tissue sample collections. The patients who underwent primary CRC radical resection at The First Hospital of China Medical University (Shenyang, China) between 2010 and 2011 were enrolled. Ninety-nine pairs of CRC tissue samples were obtained with matched normal adjacent tissues (NATs) that were distant from the tumor edges $(>5 \mathrm{~cm})$. All the samples were snap-frozen in liquid nitrogen and then stored at $-80^{\circ} \mathrm{C}$ for further use. All of the patients were diagnosed by histopathological examination and none of the patients received any preoperative treatment. Clinicopathological data and follow-up information were obtained from the medical records and the responses from the patients or their relatives. Informed consent was obtained from all the participants, and this study was approved by the Research Ethics Committee of China Medical University.

RNA isolation from tissues. Total RNA was extracted from tissue samples using TRIzol Reagent (Ambion, Thermo Fisher, Waltham, MA, USA) according to the manufacturer's protocol. The quality of the RNA was determined by UV spectrophotometry using a nano photometer UV/Vis spectrophotometer (Implen, Schatzbogen, Munich, Germany) and a standard of A260 nm/A280 nm > 1.9.

Reverse transcription (RT) and real-time (RT)-polymerase chain reaction (PCR). The residual DNA in the RNA sample was eliminated and complementary DNA was synthesized using a PrimerScript RT reagent kit (TaKaRa Bio, Inc., Otsu, Japan) according to the manufacturer's protocol. The relative expression level of lncRNA RP1-13P20.6 in all the samples was determined using the SYBR Premix Ex Taq II (TaKaRa Bio) on a Light Cycler 480 II Real-Time PCR system (Roche Diagnostics, Basel, Switzerland) with the following reaction conditions: one cycle at $95^{\circ} \mathrm{C}$ for $5 \mathrm{~s}, 60^{\circ} \mathrm{C}$ for $30 \mathrm{~s}, 72^{\circ} \mathrm{C}$ for $30 \mathrm{~s}$, and $45 \mathrm{cycles}$ for all incubations. The level of relative expression was normalized to glyceraldehyde 3-phosphate dehydrogenase (GAPDH) as an endogenous reference using the $\Delta \mathrm{Ct}$ method. The primers used in this study were as follows: GAPDH primer: 5'-CGGATTTGGTCGTATTGGG-3' (forward) and 5'-CTGGAAGATGGTGATGGGATT-3' (reverse); RP1-13P20.6 primer: 5' $^{\prime}$ TCATGTTTCCAGCAGGGCAA-3' (forward) and 5'-GCAGCCACACTTCACACTTG-3' (reverse).

Statistical analysis. The relative expression levels of IncRNA RP1-13P20.6 in CRC tissues were calculated relative to the NATs as controls using the $2^{-\Delta \Delta C t}$ formula and the rela- tive expression was presented as the fold-change. $\Delta \mathrm{Ct}$ is the difference between $\mathrm{Ct}$ values of the target and the endogenous reference GAPDH $\left(\Delta \mathrm{Ct}=\mathrm{Ct}_{\mathrm{lncRNA}}-\mathrm{Ct}_{\mathrm{GAPDH}}\right)$ and $\Delta \Delta \mathrm{Ct}$ is the difference between the $\Delta \mathrm{Ct}$ value of cancerous tissues and NATs $\left(\Delta \Delta \mathrm{Ct}=\Delta \mathrm{Ct}_{\text {cancerous IncRNA }}-\Delta \mathrm{Ct}_{\mathrm{NAT} \text { IncRNA }}\right)$. All statistical analyses were performed by SPSS software, version 19.0 (SPSS, Inc., Chicago, IL, USA) and nonparametric tests were mainly used in this study. The Wilcoxon test was used to analyze the difference between the expression of lncRNA RP1-13P20.6 in cancerous tissues and NATs. The correlation between lncRNA expression and clinicopathological parameters was evaluated by the Mann-Whitney U test and the Kruskal-Wallis test for two groups and three groups or more, respectively. The Kaplan-Meier method and the log-rank test were used to depict the curves for survival and to analyze the statistical difference of survival times between the highly expressed group and poorly expressed group. Cox's proportional hazards regression model was used to calculate the hazard ratio (HR) with $95 \%$ confidence interval ( $95 \% \mathrm{CI}$ ). A receiver operating characteristic (ROC) curve was used to estimate the diagnostic value of lncRNA RP1-13P20.6 for CRC. The Youden index with corresponding sensitivity and specificity was calculated according to the formula Youden index $=$ maximum (sensitivity + specificity -1$) \approx$ maximum (sensitivity-[1- specificity]). Two-tailed $\mathrm{p}$ values were considered as statistically significant when they were less than 0.05 .

\section{Results}

General characteristics of the enrolled patients. Among the 99 cases, the proportions of the male and female CRC diagnosed patients were almost equal (51.5\% vs. $48.5 \%$, respectively). The median age of the patients was 65 years (range, 28-84 years) and the median tumor length in diameter was 5.5 centimeters (range, $1.8-13 \mathrm{~cm}$ ). The tumors were located in the colon or rectum and the majority of the tumors were diagnosed at well or moderately differentiated grades. All of the patients were followed-up and examined on time. The details of the patients are shown in Table 1.

Expression of RP1-13P20.6 in tissues. We determined the relative expression levels of lncRNA RP1-13P20.6 in cancerous tissues compared with their NATs. As shown in Figure 1, lncRNA RP1-13P20.6 was downregulated significantly in the cancerous tissues compared to NATs, as determine by real-time PCR $(\mathrm{p}<0.001)$ (Figure 1A). Of the cases, 83.8\% (83/99) showed downregulated expression of lncRNA RP113 P20.6 and 76 of them showed a reduction of more than 50\% (Figure 1B).

Correlations between RP1-13P20.6 expression in cancerous tissues and clinical characteristics. We estimated the correlation between the expression level and clinicopathological characteristics. As shown in Table 1, we analyzed the expression level of lncRNA RP1-13P20.6 in different groups that were classified according to tumor size, histological grade, and pathological stage. However, there was no statistically 

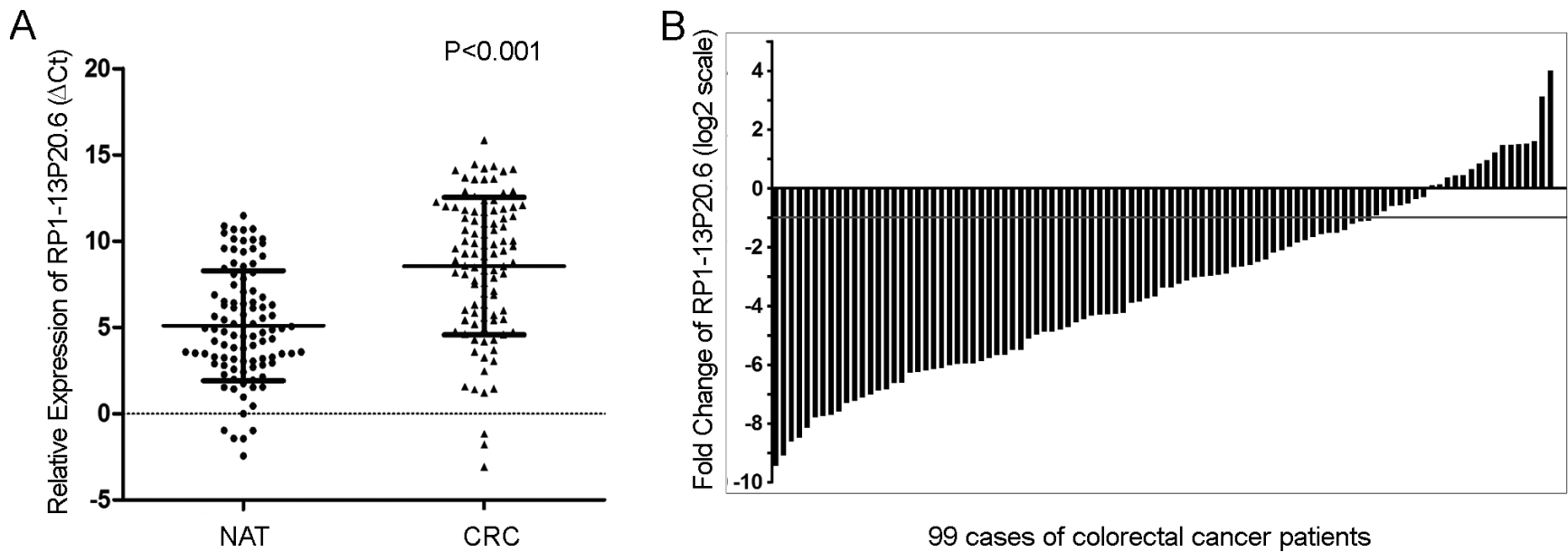

Figure 1. Expression level of RP1-13P20.6 in 99 CRC patients. A. The expression levels of colorectal cancer (CRC) tissues compared with non-tumor adjacent tissues (NATs) are detected by quantitative polymerase chain reaction and the data are presented as the mean \pm standard error of 3 times of independent experiments. Being normalized to GAPDH, a higher $\Delta \mathrm{Ct}$ indicates a lower expression and the expression of IncRNA RP1-13P20.6 in CRC tissues is lower than NATs. B. the relative expression of IncRNA RP1-13P20.6 in 99 CRC tissues are presented as $\log 2$ transformed fold change and 83 of the 99 patients are decreased.

Table 1. The relative expression level of IncRNA RP1-13P20.6 and the relationship with cliniopathological characteristics

\begin{tabular}{|c|c|c|c|c|}
\hline Characteristics & $\begin{array}{c}\text { No. of } \\
\text { patients }\end{array}$ & Percent & RP1-13P20.6* & $P$ value \\
\hline Gender & & & & 0.540 \\
\hline Male & 51 & $51.5 \%$ & $0.10(0.02-0.45)$ & \\
\hline Female & 48 & $48.5 \%$ & $0.07(0.11-0.44)$ & \\
\hline Tumor location & & & & 0.836 \\
\hline colon & 45 & $45.5 \%$ & $0.05(0.01-0.68)$ & \\
\hline rectum & 54 & $54.5 \%$ & $0.11(0.02-0.32)$ & \\
\hline Age & & & & 0.120 \\
\hline$<65$ & 47 & $47.5 \%$ & $0.13(0.02-0.77)$ & \\
\hline$\geq 65$ & 52 & $52.5 \%$ & $0.06(0.01-0.27)$ & \\
\hline Tumor size & & & & 0.366 \\
\hline$<5.5 \mathrm{~cm}$ & 48 & $48.5 \%$ & $0.08(0.02-0.32)$ & \\
\hline$\geq 5.5 \mathrm{~cm}$ & 51 & $51.5 \%$ & $0.11(0.01-0.77)$ & \\
\hline Histological grade & & & & 0.307 \\
\hline well differentiated & 14 & $14.1 \%$ & $0.05(0.01-0.23)$ & \\
\hline moderately differentiated & 78 & $78.8 \%$ & $0.10(0.02-0.48)$ & \\
\hline Poorly or undifferentiated & 7 & $7.1 \%$ & $0.15(0.05-1.79)$ & \\
\hline Tumor invasion depth & & & & 0.393 \\
\hline $\mathrm{T} 1+\mathrm{T} 2$ & 15 & $15.2 \%$ & $0.16(0.07-0.34)$ & \\
\hline $\mathrm{T} 3+\mathrm{T} 4$ & 84 & $84.8 \%$ & $0.61(0.16-0.51)$ & \\
\hline Lymph node metastasis & & & & 0.579 \\
\hline negative & 60 & $60.6 \%$ & $0.09(0.02-0.35)$ & \\
\hline positive & 39 & $39.4 \%$ & $0.11(0.02-0.58)$ & \\
\hline TNM stage & & & & 0.617 \\
\hline stage I & 12 & $12.1 \%$ & $0.19(0.04-0.35)$ & \\
\hline stage II & 49 & $49.5 \%$ & $0.05(0.02-0.45)$ & \\
\hline stage III & 37 & $37.4 \%$ & $0.07(0.02-0.51)$ & \\
\hline stage IV & 1 & $1 \%$ & 0.60 & \\
\hline
\end{tabular}

${ }^{*}$ Median of relative expression, with 25 th-75th percentile in parenthesis significant difference observed between these groups $(\mathrm{p}>$ 0.05).

Correlations between IncRNA RP1-13P20.6 expression level and patients' survival. According to the median relative expression level of RP1-13P20.6 in cancerous tissues, the 99 patients were divided into two groups: the high expression group and the low expression group. The overall survival time was used to assess the correlation with IncRNA RP1-13P20.6 expression. The survival curves are shown in Figure 2. However, the differences in expression levels between the two groups showed no statistical significance. The univariate analyses demonstrated that lymphatic metastasis $(\mathrm{p}<0.05)$ was a risk factor for $\mathrm{CRC}$ patients' survival. Nevertheless, univariate did not reveal any statistical significance of prognostic value of RP1-13P20.6 for CRC (Table 2).

Diagnostic potential of RP1-13P20.6 in CRC. The ROC curve and area under the curve (AUC) were used to evaluate the potential of lncRNA RP1-13P20.6 in diagnosing CRC. The relative expression levels of RP1-13P20.6 were obtained from the results of real-time PCR. The AUC was 0.755 (95\% potential, $0.688-0.823, \mathrm{p}<0.001$ ) (Figure 3), the Youden index was 0.425 , and the sensitivity and specificity were 0.657 and 0.768 , respectively.

\section{Discussion}

Non-coding genomic nucleotides are regarded as having important roles in regulating tumor progression both in vitro and in vivo. These RNAs stimulate or inhibit cell proliferation, apoptosis, differentiation, and metastasis by regulating chromatin modification, transcription, and posttranscriptional processing to affect the progression of multiple cancers [22-23]. LncRNA RP1-13P20.6 is a 1997 nt RNA with two exons and 


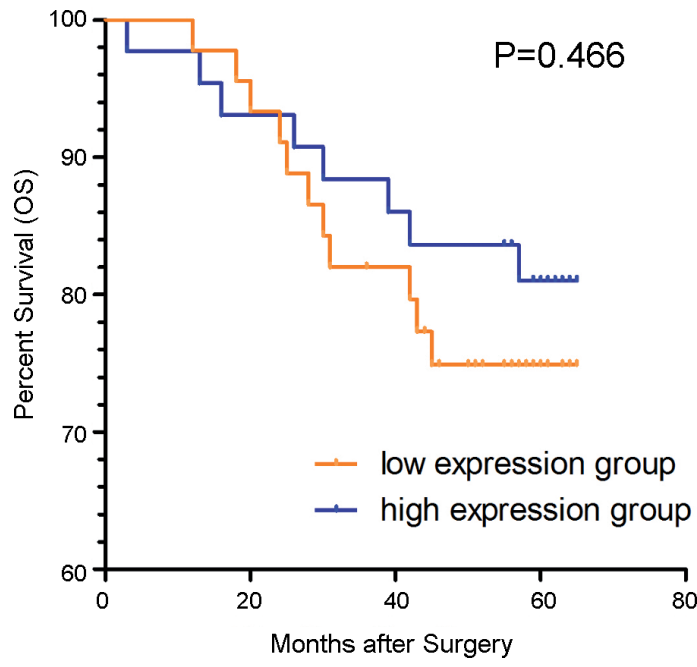

Figure 2. The survival curves of patients with different expressed level of IncRNA RP1-13P20.6. The overall survival time of the patients enrolled are divided into 2 groups: low expression group and high expression group. There isn't any significant difference between the two groups. $(\mathrm{P}=0.466)$.

one intron. In this study, we found that lncRNA RP1-13P20.6 was decreased significantly in CRC tissues.

Recently, aberrantly expressed lncRNAs have been found related with CRC. As examples, lncRNAs such as CCAT1 [24-25], CCAT2 [26], HOTAIR [27] and MALAT1[28] are increased in CRC tissues compared to NATs and have been identified as oncogenes. The lncRNAs can regulate the expression of their target genes, activate some signaling pathways, and promote cell proliferation, metastasis, and tumor recurrence [29-32]. However, lncRNAs such as MEG3, FER1L4 and ncRAN are downregulated in both cancerous tissues and cell lines [33-35]. These lncRNAs function as tumor suppressors and inhibit the proliferative and invasive ability of tumor cells. In our study, we observed that lncRNA RP1-13P20.6 was downregulated significantly in CRC patients and was decreased by more than $50 \%$ in the majority of the patients. Thus, we presume that lncRNA RP1-13P20.6 likely plays a suppressive role in the genesis and development of CRC. However, lncRNA functions in tumorigenesis are not clearly understood because of their high tissue specificity and individual differences. The mechanism of lncRNA RP1-13P20.6 in CRC remains unknown and requires further studies.

Although new treatments for CRC have been developed, CRC still shows high mortality. Because of the unrecognized symptoms, patients are often treated at an advanced stage which leads to the 5-year survival rate still being 50\%-60\% [36]. It is therefore vital to identify molecular biomarkers for early diagnosis. Aberrantly expressed proteins and mRNAs have been used as auxiliary tools in diagnosing multiple cancers. Recently, lncRNAs have also been identified as potential indicators in diagnosing multiple cancers, such as gastric cancer [37]. Because significant differences were observed

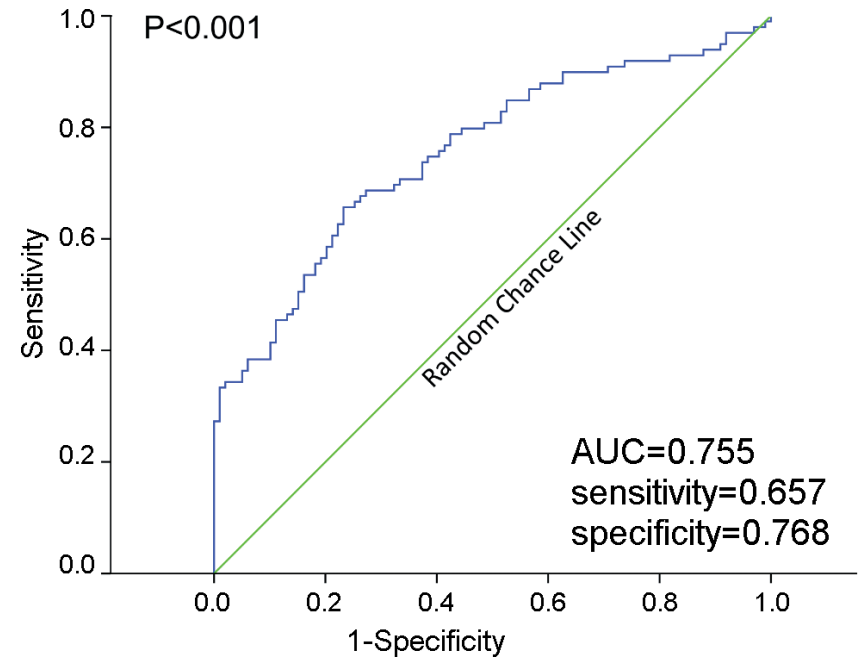

Figure 3. Receiver operating characteristic curve (ROC) of CRC patients based on the expression of RP1-13P20.6. The area under curve (AUC) is up to 0.755 . $(\mathrm{P}<0.001)$

between cancerous tissues and NATs in this study, lncRNA RP1-13P20.6 may be a potential biomarker for CRC. To our best knowledge, the ROC and AUC are often used as tools to evaluate diagnostic tests. The AUC of lncRNA RP1-13P20.6 in CRC was up to 0.755 , with 0.657 and 0.768 for sensitivity and specificity, respectively. This suggests that lncRNA RP113P20.6 has good diagnostic accuracy in distinguishing tumor tissues from normal tissues [38].

The cis effect is one of the common mechanisms of lncRNA regulatory functions, suggesting that lncRNAs could regulate the expression of proximal genes [39]. Based on bioinformatics analyses, lncRNA RP1-13P20.6 is located at the chromosome $1 \mathrm{q} 12$ region, near the small proline-rich proteins-SPRR family encoding region [21]. The SPRR gene is a kind of epidermal differentiation complex gene that participates in the late differentiation of epithelial cells and the formation of an envelope to protect underlying tissues [40]. It has been reported that, SPRRs are related to the allergic responses in gastrointestinal mucosa and other tissues [41]. Aberrant expressions of

Table 2. Univariate analysis for overall survival of the 99 patients

\begin{tabular}{lccc}
\hline Variables & HR & $\mathbf{9 5 \% ~ C I ~}$ & P value \\
\hline Gender & 1.275 & $0.513-3.170$ & 0.601 \\
Age & 1.017 & $0.973-1.062$ & 0.458 \\
Tumor size & 1.070 & $0.878-1.304$ & 0.504 \\
Depth of invasion & 2.635 & $0.768-9.048$ & 0.124 \\
Expression of RP1-13P20.6 & 1.400 & $0.562-3.484$ & 0.470 \\
Lymph nodes metastasis & 3.834 & $1.453-10.115$ & $0.007^{\star}$ \\
\hline
\end{tabular}

HR: hazard ratio, 95\% CI: 95\% confidence interval.

${ }^{*}$ Indicated statistical significance $(\mathrm{P}<0.05)$. 
SPRRs were detected in esophageal squamous cell cancers, small-cell lung carcinoma, CRC, and head and neck cancers [42-43]. SPRR3 (one kind of SPRR gene) was upregulated in CRC tissues and is closely related with lymphatic metastasis. It was also reported that SPRR3 affected cell proliferation by the AKT pathway, which suggests a new role in CRC genesis [44]. Thus, we presume that lncRNA RP1-13P20.6 may take part in the genesis and progression of CRC through regulating $S P R R$ s, especially SPRR3 which has been verified as related with CRC and which has an oncogenic role. Because lncRNA RP1-13P20.6 and SPRR3 are dysregulated in CRC, and lncRNA RP1-13P20.6 is decreased, and SPRR3 increased, there may be an inverse relationship between lncRNA RP1-13P20.6 and SPRR3. A possible mechanism whereby lncRNA RP1-13P20.6 may regulate SPRR3 are as follows: IncRNAs act as precursors of miRNAs to degrade mRNAs through assembly of RNAinduced silencing complexes (RISC) [45-46] or impair the stability of mRNAs [47]. However, the exact mechanism by which lncRNA RP1-13P20.6 regulates SPRR3 is still unclear and requires further investigation.

In conclusion, the expression of RP1-13P20.6 decreases significantly in colorectal cancerous tissues and it could serve as a potential biomarker and therapeutic target in CRC.

Acknowledgements: We thank to the department of Surgical Oncology of First Hospital of China Medical University for providing human colorectal tissue samples. We also thank the College of China Medical University for technical assistance in experiments. This work was supported by National Science Foundation of China (81372549, 81372550), the Special Prophase Program for National Key Basic Research Program of China (No.2014CB560712) and Clinical Capability Construction Project for Liaoning Provincial Hospitals (LNCCC-A01-2014)

\section{References}

[1] TORRE L A, BRAY F, SIEGEL RL, FERLAY J, LORTETTIEULENT J et al. Global cancer statistics, 2012. CA Cancer J Clin 2015; 65: 87-108. http://dx.doi.org/10.3322/ caac. 21262

[2] CHEN W, ZHENG R, BAADE P D, ZHANG S, ZENG H et al. Cancer statistics in China, 2015. CA Cancer J Clin 2016; 66: 115-132. http://dx.doi.org/10.3322/caac.21338

[3] ZHENG R, ZENG H, ZHANG S, CHEN T, CHEN W. National estimates of cancer prevalence in China, 2011. Cancer Lett 2016; 370: 33-38. http://dx.doi.org/10.1016/j. canlet.2015.10.003

[4] WANG K C, CHANG H Y. Molecular mechanisms of long noncoding RNAs. Mol Cell 2011; 43: 904-914. http://dx.doi. org/10.1016/j.molcel.2011.08.018

[5] PONTING C P, OLIVER P L, REIK W. Evolution and functions of long noncoding RNAs. Cell 2009; 136: 629-641. http:// dx.doi.org/10.1016/j.cell.2009.02.006

[6] MERCER T R, DINGER M E, MATTICK J S. Long noncoding RNAs: insights into functions. Nat Rev Genet 2009; 10: 155-159. http://dx.doi.org/10.1038/nrg2521
[7] MARQUES A C, PONTING C P. Catalogues of mammalian long noncoding RNAs: modest conservation and incompleteness. Genome Biol 2009; 10: R124. http://dx.doi.org/10.1186/ gb-2009-10-11-r124

[8] XU S, WANG P, YOU Z, MENG H, MU G et al. The long noncoding RNA EPB41L4A-AS2 inhibits tumor proliferation and is associated with favorable prognoses in breast cancer and other solid tumors. Oncotarget 2016; 7: 20704-20717. http:// dx.doi.org/10.18632/oncotarget.8007

[9] GE Y, YAN X, JIN Y, YANG X, YU X et al. fMiRNA-192 and miRNA-204 Directly Suppress lncRNA HOTTIP and Interrupt GLS1-Mediated Glutaminolysis in Hepatocellular Carcinoma. PLoS Genet 2015; 11: e1005726. http://dx.doi. org/10.1371/journal.pgen.1005726

[10] LIU X H, SUN M, NIE F Q, GE Y B, ZHANG E B et al Lnc RNA HOTAIR functions as a competing endogenous RNA to regulate HER2 expression by sponging miR-331-3p in gastric cancer. Mol Cancer 2014; 13: 92. http://dx.doi. org/10.1186/1476-4598-13-92

[11] HAN Y, WU Z, WU T, HUANG Y, CHENG Z et al. Tumorsuppressive function of long noncoding RNA MALAT1 in glioma cells by downregulation of MMP2 and inactivation of ERK/MAPK signaling. Cell Death Dis 2016; 7: e2123. http:// dx.doi.org/10.1038/cddis.2015.407

[12] WANG Y, WANG Y, LI J, ZHANG Y, YIN H et al. CRNDE, a long-noncoding RNA, promotes glioma cell growth and invasion through mTOR signaling. Cancer Lett 2015; 367: 122-128. http://dx.doi.org/10.1016/j.canlet.2015.03.027

[13] YIN D, HE X, ZHANG E, KONG R, DE W et al. Long noncoding RNA GAS5 affects cell proliferation and predicts a poor prognosis in patients with colorectal cancer. Med Oncol 2014; 31: 253. http://dx.doi.org/10.1007/s12032-014-0253-8

[14] LIANG W C, FU W M, WONG C W, WANG Y, WANG W M et al. The lncRNA H19 promotes epithelial to mesenchymal transition by functioning as miRNA sponges in colorectal cancer. Oncotarget 2015; 6: 22513-22525. http://dx.doi. org/10.18632/oncotarget.4154

[15] TUCK A C, TOLLERVEY D. A transcriptome-wide atlas of RNP composition reveals diverse classes of mRNAs and lncRNAs. Cell 2013; 154: 996-1009. http://dx.doi. org/10.1016/j.cell.2013.07.047

[16] RASHID F, SHAH A, SHAN G. Long Non-coding RNAs in the Cytoplasm. Genomics Proteomics Bioinformatics 2016; 14: 73-80. http://dx.doi.org/10.1016/j.gpb.2016.03.005

[17] CARLEVARO-FITA J, RAHIM A, GUIGO R, VARDY L A, JOHNSON R. Cytoplasmic long noncoding RNAs are frequently bound to and degraded at ribosomes in human cells. RNA 2016; 22: 867-882. http://dx.doi.org/10.1261/ $\underline{\text { rna.053561.115 }}$

[18] TIANWEN LI X M, LIYUN FU, BINGXIU XIAO AND JUNMING GUO. Molecular mechanisms of long noncoding RNAs on gastric cancer. Oncotarget 2016; 7: 8601-8612.

[19] CAO C, SUN J, ZHANG D, GUO X, XIE L et al. The long intergenic noncoding RNA UFC1, a target of MicroRNA 34a, interacts with the mRNA stabilizing protein HuR to increase levels of beta-catenin in HCC cells. Gastroenterology 2015; 148 : 415-426.e418. http://dx.doi.org/10.1053/j.gastro.2014.10.012 
[20] NIU Y, SHAO Z, WANG H, YANG J, ZHANG F et al. LASP1S100A11 axis promotes colorectal cancer aggressiveness by modulating TGFbeta/Smad signaling. Sci Rep 2016; 6: 26112. http://dx.doi.org/10.1038/srep26112

[21] MISCHKE D, KORGE B P, MARENHOLZ I, VOLZ A, ZIEGLER A. Genes encoding structural proteins of epidermal cornification and $\mathrm{S} 100$ calcium-binding proteins form a gene complex („epidermal differentiation complex“) on human chromosome 1q21. J Invest Dermatol 1996; 106: 989-992. http://dx.doi.org/10.1111/1523-1747.ep12338501

[22] XIE X, TANG B, XIAO Y F, XIE R, LI B S et al. Long non-coding RNAs in colorectal cancer. Oncotarget 2015; 7:5226-5239.

[23] GUTTMAN M, RINN J L. Modular regulatory principles of large non-coding RNAs. Nature 2012; 482: 339-346. http:// dx.doi.org/10.1038/nature10887

[24] NISSAN A, STOJADINOVIC A, MITRANI-ROSENBAUM S, HALLE D, GRINBAUM R et al. Colon cancer associated transcript-1: a novel RNA expressed in malignant and premalignant human tissues. Int J Cancer 2012; 130: 1598-1606. http://dx.doi.org/10.1002/ijc.26170

[25] ALAIYAN B, ILYAYEV N, STOJADINOVIC A, IZADJOO $\mathrm{M}$, ROISTACHER $\mathrm{M}$ et al. Differential expression of colon cancer associated transcript1 (CCAT1) along the colonic adenoma-carcinoma sequence. BMC cancer 2013; 13: 196. http://dx.doi.org/10.1186/1471-2407-13-196

[26] LING H, SPIZZO R, ATLASI Y, NICOLOSO M, SHIMIZU $\mathrm{M}$ et al. CCAT2, a novel noncoding RNA mapping to 8q24, underlies metastatic progression and chromosomal instability in colon cancer. Genome Res 2013; 23: 1446-1461. http:// dx.doi.org/10.1101/gr.152942.112

[27] RINN J L, KERTESZ M, WANG J K, SQUAZZO S L, XU X et al. Functional demarcation of active and silent chromatin domains in human HOX loci by noncoding RNAs. Cell 2007; 129: 1311-1323. http://dx.doi.org/10.1016/j.cell.2007.05.022

[28] JI Q, ZHANG L, LIU X, ZHOU L, WANG W et al. Long noncoding RNA MALAT1 promotes tumour growth and metastasis in colorectal cancer through binding to SFPQ and releasing oncogene PTBP2 from SFPQ/PTBP2 complex. Br J Cancer 2014; 111: 736-748. http://dx.doi.org/10.1038/bjc.2014.383

[29] HE X, TAN X, WANG X, JIN H, LIU L et al. C-Myc-activated long noncoding RNA CCAT1 promotes colon cancer cell proliferation and invasion. Tumour Biol 2014; 35: 12181-12188. http://dx.doi.org/10.1007/s13277-014-2526-4

[30] XIANG J F, YIN Q F, CHEN T, ZHANG Y, ZHANG X O et al. Human colorectal cancer-specific CCAT1-L lncRNA regulates long-range chromatin interactions at the MYC locus. Cell Res 2014; 24: 513-531. http://dx.doi.org/10.1038/cr.2014.35

[31] YANG M H, HU Z Y, XU C, XIE L Y, WANG X Y et al. MALAT1 promotes colorectal cancer cell proliferation/ migration/invasion via PRKA kinase anchor protein 9. Biochim Biophys Acta 2015; 1852: 166-174. http://dx.doi. org/10.1016/j.bbadis.2014.11.013

[32] JI Q, LIU X, FU X, ZHANG L, SUI H et al. Resveratrol inhibits invasion and metastasis of colorectal cancer cells via MALAT1 mediated Wnt/beta-catenin signal pathway. PloS One 2013; 8: e78700. http://dx.doi.org/10.1371/journal.pone.0078700
[33] YUE B, SUN B, LIU C, ZHAO S, ZHANG D et al. Long noncoding RNA Fer-1-like protein 4 suppresses oncogenesis and exhibits prognostic value by associating with miR-106a-5p in colon cancer. Cancer Sci 2015; 106: 1323-1332. http://dx.doi. org $/ 10.1111 /$ cas. 12759

[34] QI P, XU M D, NI S J, SHEN X H, WEI P et al. Downregulation of ncRAN, a long non-coding RNA, contributes to colorectal cancer cell migration and invasion and predicts poor overall survival for colorectal cancer patients. Mol Carcinog 2015; 54: 742-750. http://dx.doi.org/10.1002/ mc. 22137

[35] YIN D D, LIU Z J, ZHANG E, KONG R, ZHANG Z H et al. Decreased expression of long noncoding RNA MEG3 affects cell proliferation and predicts a poor prognosis in patients with colorectal cancer. Tumour Biol 2015; 36: 4851-4859. http:// dx.doi.org/10.1007/s13277-015-3139-2

[36] KUMAR R, PRICE T J, BEEKE C, JAIN K, PATEL G et al. Colorectal cancer survival: An analysis of patients with metastatic disease synchronous and metachronous with the primary tumor. Clin Colorectal Cancer 2014; 13: 87-93. http:// dx.doi.org/10.1016/j.clcc.2013.11.008

[37] CUI Z, CHEN Y, XIAO Z, HU M, LIN Y et al. Long noncoding RNAs as auxiliary biomarkers for gastric cancer screening: A pooled analysis of individual studies. Oncotarget 2016; 7: 25791-25800. http://dx.doi.org/10.18632/ oncotarget.8268

[38] CARTER J V, PAN J, RAI S N, GALANDIUK S. ROC-ing along: Evaluation and interpretation of receiver operating characteristic curves. Surgery 2016. http://dx.doi.org/10.1016/j. surg.2015.12.029

[39] ZHAO J H, SUN J X, SONG Y X, CHEN X W, YANG Y C et al. A novel long noncoding RNA-LOWEG is low expressed in gastric cancer and acts as a tumor suppressor by inhibiting cell invasion. J Cancer Res Clin Oncol 2016; 142: 601-609. http://dx.doi.org/10.1007/s00432-015-2071-6

[40] MARTINET N, BENINATI S, NIGRA T P, FOLK J E. N1N8-bis(gamma-glutamyl)spermidine cross-linking in epidermal-cell envelopes. Comparison of cross-link levels in normal and psoriatic cell envelopes. Biochem J 1990; 271: 305-308. http://dx.doi.org/10.1042/bj2710305

[41] ZIMMERMANN N, DOEPKER M P, WITTE D P, STRINGER K F, FULKERSON P C et al. Expression and regulation of small proline-rich protein 2 in allergic inflammation. Am J Respir Cell Mol Biol 2005; 32: 428-435. http://dx.doi.org/10.1165/ rcmb.2004-0269OC

[42] CARREGARO F, STEFANINI A C, HENRIQUE T, TAJARA E H. Study of small proline-rich proteins (SPRRs) in health and disease: a review of the literature. Arch Dermatol Res 2013; 305: 857-866. http://dx.doi.org/10.1007/s00403-013$\underline{1415-9}$

[43] TYSZKIEWICZ T, JARZAB M, SZYMCZYK C, KOWAL M, KRAJEWSKA J et al. Epidermal differentiation complex (locus 1q21) gene expression in head and neck cancer and normal mucosa. Folia Histochem Cytobiol 2014; 52: 79-89. http:// dx.doi.org/10.5603/FHC.2014.0018

[44] CHO D H, JO Y K, ROH S A, NA Y S, KIM T W et al. Upregulation of SPRR3 promotes colorectal tumorigen- 
esis. Mol Med 2010; 16: 271-277. http://dx.doi.org/10.2119/ molmed.2009.00187

[45] TIJSTERMAN M, PLASTERK R H. Dicers at RISC; the mechanism of RNAi. Cell 2004; 117: 1-3. http://dx.doi. org/10.1016/S0092-8674(04)00293-4

[46] MATOUK I J, RAVEH E, ABU-LAIL R, MEZAN S, GILON $\mathrm{M}$ et al. Oncofetal H19 RNA promotes tumor metastasis.
Biochim Biophys Acta 2014; 1843: 1414-1426. http://dx.doi. org/10.1016/j.bbamcr.2014.03.023

[47] KRETZ M, SIPRASHVILI Z, CHU C, WEBSTER D E, ZEHNDER A et al. Control of somatic tissue differentiation by the long non-coding RNA TINCR. Nature 2013; 493: 231-235. http://dx.doi.org/10.1038/nature11661 